\title{
Information Infrastructure for Information Delivery and Development of Rural Communities in Nigeria: A Review
}

\author{
K. N. IGWE (Corresponding author) \\ Department of Library and Information Science \\ Akanu Ibiam Federal Polytechnic Unwana, Ebonyi State, Nigeria \\ E-mail: knigwe@yahoo.com \\ Elizabeth O. NDUBUISI-OKOH \\ The Polytechnic Library \\ Akanu Ibiam Federal Polytechnic Unwana, Ebonyi State, Nigeria \\ E-mail: nancyukah@gmail.com \\ Odionyenfe Osim AKUMA \\ Department of General Studies \\ Akanu Ibiam Federal Polytechnic Unwana, Ebonyi State, Nigeria \\ E-mail: odyakuma@yahoo.com

\section{Chukwu OKOCHE} \\ The Polytechnic Library \\ AkanuIbiam Federal PolytechnicUnwana, Ebonyi State, Nigeria \\ E-mail: ezinnechux@yahoo.com
}

Received: February 9, 2015 Accepted: March 9, 2015 Published: March 24, 2015

doi:10.5296/ijssr.v3i1.7068 URL: http://dx.doi.org/10.5296/ijssr.v3i1.7068 


\section{Abstract}

The focus of this paper is on information infrastructures that are required for information delivery and development of rural communities in Nigeria. It x-rayed the concepts of information infrastructure, and its types for information delivery in rural areas, which are community information centres, rural school media centres, rural information and communication technology centres as well as community radio stations. The paper concluded that the absence of these rural information infrastructures is affecting the provision of information to rural dwellers, and therefore made a case for governments to factor rural information infrastructures in their development programmes for communities in Nigeria.

Keywords: Information Infrastructure, Community Information Centres, Rural School Media Centres, Rural Information and Communication Technology Centres, Community Radio Stations.

\section{Introduction}

Development of a nation requires that the urban metropolis, semi-urban cities and rural communities be given adequate and equal consideration in the formulation of policies and implementation of programmes. This no doubt will give all the nooks and crannies of the country a sense of belonging, thereby minimizing rural-urban migration that results in congestion of cities and metropolitan towns. However in Nigeria, there seems to be more concentration of the government developmental projects in the urban areas and city centres, with little or no attention to rural communities. That is why Akpomuvie (2010) opines that one of the characteristics of developing countries like Nigeria is the increasing disparity between the urban and rural areas, noting that a dangerous gap exists in the developmental levels of urban cities and rural areas. This is related to the observation by Issa (1998) that the rural populace suffers from acute low productivity, social and economic retrogression due mainly to ignorance which is also a direct consequence of either inadequate or total lack of information provision to them. This depicts the absence of relevant information infrastructures for addressing rural dwellers' information delivery and development challenges. Thus, the situation will undoubtedly continue to raise questions among rural dwellers, on whether they are still part of the larger society or not.

Rural development generally refers to the process of improving the quality of life and economic well-being of people living in relatively isolated and sparsely populated areas (Moseley, 2003). Rural development has traditionally centered on the exploitation of land-intensive natural resources such as agriculture and forestry. However, changes in global production networks and increased urbanization have changed the character of rural areas. Increasingly tourism, niche manufacturers, and recreation have replaced resource extraction and agriculture as dominant economic drivers (Ward \& Brown, 2009). The need for rural communities to approach development from a wider perspective has created more focus on a broad range of development goals rather than merely creating incentive for agricultural or resource based businesses. Education, entrepreneurship, physical infrastructure, and social infrastructure all play an important role in developing rural communities. Rural development is also characterized by its emphasis on locally produced economic development strategies. 
In contrast to urban cities, which have many similarities, rural areas are highly distinctive from one another. For this reason, there is a large variety of rural development approaches used globally. Rural development actions are mainly and mostly for the social and economic development of the rural areas (Chigbu, 2012).

From another perspective, Akpomuvie (2010) posits that rural community development includes all strategies, interventions or coordinated activities at the community level aimed at bringing about social and economic development to the people at the grass roots. Akpomuvie quoted Idiode, who identified three major approaches to rural community development in Nigeria, which are: the extension approach, the project approach and the service approach.

a. The extension approach involves directly teaching the rural people improved methods and techniques of farming, health care or how to read and write.

b. The project approach to community development is generally motivated by the government's desire to improve the economic conditions in the areas. It is, therefore, characterized by the establishment of economic ventures, such as government farms or rural industries. In the government circles in Nigeria, the project approach to community development is usually referred to as "rural development."

c. The service approach to community development calls for active anticipation and initiative of the local people. Used as the main strategy for rural community development in Nigeria, the service approach concentrates on the provision of social amenities such as postal agencies, maternity centres, pipe-borne water, dispensaries, electricity, etc, in the rural areas. These are provided at the initiative of the community itself. The service approach to community development is known as "self-help”.

However, notwithstanding the perspective and approach, there are certain infrastructures in the information sector, which are required for the delivery of information services and provision of information needs of rural inhabitants, thereby contributing to development of rural communities in Nigeria. This therefore positions information, emphasizing it as a tool for development of the grass-roots and the hinterlands. Uhegbu (2014) notes that the emphasis becomes more urgent because of the level of social and infrastructural decay, non-existent social and economic facilities, unemployment and security challenges at the grassroots sustained by persistent ignorance, superstition, rumour mongering, and lack of self-will by the grassroots. Uhegbu further posits that:

the dangerous activities of kidnappers, militants and insurgents, and the outbreak of ebola virus disease in Nigeria require that the rural areas must be continually informed of the goings on in the fight against these challenges. Thus, information becomes the key ingredient to accomplish these and unlock the potentials of people at the grassroots, re-align their thought processes, mobilize them for social, economic, environmental and political activities, which will in turn increase the standard of living of the grassroots (Uhegbu, 2014).

According to Meyer as elaborated by Opara (2014), certain characteristics of information make it a critical development resource. These are its ability to act as a dynamic force that 
drives the recipients to action;extend the knowledge base of its recipient;increase and broaden the perceptions of its users or recipients;enhance their competencies through the knowledge and skills they gain;improve their self-esteem; and also its ability to be regenerative and versatile. Meanwhile, various documentations in the literature have shown that rural dwellers in our communities need unhindered access to information to enable them to be better informed for decision-making involving all aspects of their life (Diso, 2005; Etebu, 2009; Harande, 2009; Momodu, 2012; Mtega, 2012; Issa, Omopupa \& Salman, 2012). These required information, which may be agricultural, health, economic, social or even academic should not only be timely, accurate and reliable, but also directly applicable and relevant to rural dwellers' continued existence and productivity in their various endeavours. But unfortunately, as pointed out by Aina (2004), the pattern of libraries in Nigeria hardly serve the rural dwellers such as artisans and farmers that are barely literate and constitute a substantial majority of the country's population; thus describing that development of library and information services in Nigeria is defective as it is geared towards a tiny minority of the society. These cases neglecting services to community inhabitants may be attributed to unavailability of relevant information infrastructure for providing access to information for the rural dwellers. These information infrastructures are the focus of this article, of which their mission, functions and nature of service delivery will be examined. Thus, all directed towards rural community development in Nigeria, if given appropriate consideration and implementation.

\section{Concept of Information Infrastructure}

Infrastructure can broadly be defined as long-term physical assets that operate and enable the provision of goods and services to people in a society (New Zealand Social Infrastructure Fund, 2009). According to Babalola (2013), infrastructure generally refers to the basic installations and facilities on which the continuance and growth of a community or state depends. Infrastructure can be classified into social, economic, technological, scientific, information infrastructure and the likes. Social facilities like roads, railways, telecommunication networks, electricity supply system and water supply system are all described as infrastructure. Infrastructural facilities have supporting and enabling functions and are shared by a large community of users. Social infrastructure, for instance, is a subset of the infrastructure sector and typically includes assets that accommodate social services, which may include schools, universities, hospitals, prisons and community housing. Social Infrastructure does not typically extend to the provision of social services, such as the provision of teachers at a school or custodial services at a prison. In contrast, economic infrastructure supports economic activity and is often characterised by 'user-pays' or demand-based revenue streams (such as tolls on toll roads or landing fees for an airport) (New Zealand Social Infrastructure Fund, 2009). 
Table 1. Examples of Infrastructure

\begin{tabular}{|c|c|}
\hline Sector & Examples \\
\hline Health & $\begin{array}{l}\text { - } \text { Medical facilities } \\
\text { - Ancillary infrastructure (e.g. offices, car-parks, training } \\
\text { facilities) }\end{array}$ \\
\hline Education & $\begin{array}{l}\text { - } \quad \text { Schools (primary and secondary) } \\
\text { - } \quad \text { Tertiary facilities } \\
\text { - } \quad \text { Residential student accommodation }\end{array}$ \\
\hline Housing & $\begin{array}{l}\text { - State or Council housing } \\
\text { - } \quad \text { Defence force housing }\end{array}$ \\
\hline Civic and Utilities & $\begin{array}{ll}\text { - } & \text { Community \& sports facilities } \\
\text { - } & \text { Local government facilities } \\
\text { - } & \text { Water and wastewater treatment } \\
\end{array}$ \\
\hline Transport & $\begin{array}{ll}\text { - } & \text { Bus stations } \\
\text { - } & \text { Park and rides } \\
\text { - } & \text { Availability-based road (excluding demand-risk toll roads) }\end{array}$ \\
\hline Corrections and Justice & $\begin{array}{ll}\text { - } & \text { Prisons } \\
\text { - } & \text { Court houses }\end{array}$ \\
\hline
\end{tabular}

Source: New Zealand Social Infrastructure Fund, 2009.

In the case of information infrastructure, Babalola (2013) notes that the concept of infrastructure has been used along with information to denote the information resources, networks, computers, software, developers, and producers which support the creation, transport, storage and use of information. To Babalola, information infrastructure denotes socio-technical systems composed of hardware, software, information content, human experts and network standards that facilitate information creation and exchange. From another angle, Igwe (2012) opines that information infrastructure consists of various capabilities, both manual and digital, for making information and knowledge available and accessible as well as for the transfer and use of information and knowledge for the actualization of aims, objectives and needs of individuals and organizations in the society. Information infrastructure has various elements that are expected to be in place for the realization of its mission. They include libraries and documentation institutions, information and knowledge centres, librarians and other information practitioners, research and development establishments, higher institutions and researchers, organizational system for coordination, communication channels, and relevant supportive national policies that support the development of infrastructures. The aggregate of all information infrastructure elements is expected to facilitate access to information and knowledge for the satisfaction of information needs of the citizens, especially those at the grass roots. 


\section{Nature of Information Needs of Inhabitants in Rural Communities}

Many authorities have presented information needs of rural dwellers through conceptual analysis and empirical reports. From conceptual angle, Harande (2009) notes that the diverse nature of rural communities indicates that their information needs are many and multidimensional. He articulated attempts made by information profession scholars in exploring the information needs of various categories of rural communities in Nigeria, which include:

i. The neighborhood: information needs in the neighborhood include problems of water supply, electricity supply, environmental sanitation, refuse disposal, road maintenance and drought.

ii. Health information on how individuals can prevent different diseases that affect them, and awareness of available healthcare delivery and what it costs.

iii. Agriculture and allied occupations: the greatest area of information needs by rural Nigerians is in agriculture. Such information needs include planting treated seeds, soil conservation, prevention of plants and animal disease, fertilizer application, farm machineries, recommended thinning practices, proper storage of farm products, marketing techniques, cooperative activities and other agro-cultural activities.

iv. Education: information needs of the existing rural schools, needs of the illiterate's and semi-illiterates. They need to have relevant information that will develop in their interest and support of teaching and learning processes.

v. Housing: rural public need information about where they can obtain loans to build houses and the type of materials to be used and where they can be easily obtained.

vi. Employment: rural communities need information on employment opportunities on taxation, investment opportunities, banking and other financial activities.

vii. Transportation: they need information on the cost of bicycles, motorcycles and vehicles and where to obtain them, as well as information on road construction and maintenance.

viii. Religion, Recreation and Culture: information is required on religions, recreations and Cultural activities.

ix. Welfare and Family matters: information is required on problems of marriage, childcare, juvenile delinquency etc.

x. Legal matters: information is needed on laws that affect the rural dwellers. Such law ranges from marriage to land.

xi. Crime and Safety: Information is required on how to prevent crimes, report crimes, role of the law enforcement agents etc.

xii. Policies and Government: information is needed on political rights of the people and how they can exercise such right. 
xiii. Land: information is needed on land tenure systems, acquisition and transfer of land etc.

xiv. Information is needed by rural inhabitants in almost all areas of human endeavors (Harande, 2009).

From empirical perspective, the study by Nnadozie, Egwim and Ossai-Onah (2010) in rural communities of Mbaitoli Local Government Area, Imo State, Nigeria reveals that agricultural information (71.1\%), economic information (66.5\%), health information (57.6\%), educational information (56.6\%), and governmental/political information (51.1\%) dominate the information needs of inhabitants in the area. Similarly, Saleh and Lasisi (2011) investigation on rural women in Borno State identified their information needs to be in the areas of agriculture (53\%), health (20\%), education (12\%), economy (11\%), political (03\%), and others (1\%). The implication of both studies that touch southern and northern Nigeria is that agriculture, health, education and economy are the major priorities of dwellers in Nigerian rural communities, and as such, they need reliable and relevant information in that regard. Thus, the development and transformation of the rural populace can only be possible, effective and relevant when their information needs are met positively and satisfactorily.

\section{What Are the Information Infrastructure for Information Delivery and Development of Rural Communities?}

The delivery of information and provision of information services for addressing information needs require both the availability of functional information infrastructure as well as the accessibility of the infrastructure resources by rural dwellers. These information infrastructure are: community information centres, rural school media centres, rural information and communication technology centres, as well as community radio stations.

Community Information Centres: Community Information Centres (CIC) according to Uzuegbu and Uzuegbu (2013) are information provision centres established to empower rural community members by proactively providing survival information and citizens' action information, often repackaged by the rural information provider through displays, pamphlets, brochures, newspapers and oral information dissemination system. The nature of community needs and appropriate services to provide are arrived at by means of consultation and participatory research with members of the community. Additional descriptions see CIC as centres that provide information to individuals responsible for rural development programmes; serve as communication bridge among the government, development agencies, and dwellers; support lifelong learning of the rural communities dwellers regardless of age and level of education, by providing educational resources aimed at promoting reading and learning; serve as centres for community general education as well as preservation of cultural resources and indigenous knowledge; sponsor educative and transformative seminars and workshops for the rural dwellers; and serve as avenue for promotion of wealth creation and entrepreneurship among rural dwellers (Uzuegbu\&Uzuegbu, 2013). UNESCO (n.d) further stressed that the focus of CIC is on acquiring, processing, storing and disseminating the information needed by the community they serve, with emphasis on taking the information to the people who needed it most. In other words, the direction of CIC is on strategies of identifying and 
satisfying information needs of individuals within the community.

The establishment of CIC in Nigeria will address information delivery challenges to rural dwellers thereby contributing to rural community development. As noted by Hansen (1995), the objectives of establishing CICs include to:

a. meet the information needs of community members where it operates;

b. render a more varied and more proactive services to the people;

c. supply information and facilities to development agencies;

d. serve as a source of community information in general;

e. contribute to the economic regeneration of the locality;

f. sustain community identity and confidence, especially via documentations;

g. serve as a supplier of teaching and learning resources/media. (Hansen, 1995)

CIC can be established by autonomous communities for their people through self help efforts or it can be developed as a branch of public library system existing in a state /nation for the existing political wards of local government areas. Whatever be the case, the emphasis is on the rural dwellers and the community housing it, for addressing their information-related needs.

Rural School Media Centres: Concepts such as school libraries, school library media centre, school lifelong learning centre, and school media centres are used interchangeably to mean the same. Rural School Media Centres (RSMC) are therefore coined to mean primary and secondary school libraries for pupils and students in rural communities. According to UNESCO/IFLA (n.d), school media centre provides information and ideas that are fundamental to functioning successfully in today's information and knowledge-based society. It equips students with life-long learning skills and develops the imagination, enabling them to live as responsible citizens. It also offers learning services and information resources that enable all members of the school community to become critical thinkers and effective users of information in all formats and media. The school media centre in rural communities will support the use of books and other information sources, ranging from the fictional to the documentary, from print to electronic, both on-site and online. Thus, it has been demonstrated that, when librarians and teachers work together, students achieve higher levels of literacy, reading, learning, problem-solving and information technology skills.

The school library is integral to the educational process. Development of literacy, information literacy, teaching, learning and culture are core mandate of school media centres in rural communities:

- supporting and enhancing educational goals as outlined in the school's mission and curriculum;

- developing and sustaining in children the habit and enjoyment of reading and learning, and the use of libraries throughout their lives; 


\section{Ml Macrothink}

International Journal of Social Science Research

ISSN 2327-5510

2015, Vol. 3, No. 1

- offering opportunities for experiences in creating and using information for knowledge, understanding, imagination and enjoyment;

- supporting all students in learning and practising skills for evaluating and using information, regardless of form, format or medium, including sensitivity to the modes of communication within the community;

- providing access to local, regional, national and global resources and opportunities that expose learners to diverse ideas, experiences and opinions;

- organizing activities that encourage cultural and social awareness and sensitivity;

- working with students, teachers, administrators and parents to achieve the mission of the school;

- proclaiming the concept that intellectual freedom and access to information are essential to effective and responsible citizenship and participation in a democracy; as well as

- promoting reading and the resources and services of the centre to the whole school community and beyond (UNESCO/IFLA, n.d).

The school library fulfills these functions by developing policies and services, selecting and acquiring resources, providing physical and intellectual access to appropriate sources of information, providing instructional facilities, and employing trained information practitioners (UNESCO/IFLA, n.d).

Rural Information and Communication Technology Centres: Rural ICT centres are defined as "a diverse range of facilities providing education and access to information and communication technologies offering training, internet and community services” (Shakeel, 2001). They are the places that offer educational training and public connectivity with computers and networks. IT knowledge centres are based on the assumption that technical education and social economics rather than technical connectivity to information will lead to empowerment. Such rural IT centre projects can be donor-managed and thus fosters communities’ economic sustainable development (Nwokoma, 2012).

According to National Information Technology Development Agency (NITDA) (2014), the Rural Information Technology Center (RITC) project, is aimed at bringing ICT to the doorstep of Nigerians by ensuring that the under-served areas get access to IT infrastructure. RITCs are built to provide a community-based platform for youth empowerment through e-learning and capacity building in information technology. It also emphasises community-based trainings in IT-enabled outsourcing and promoting equitable access to education, information, and technology. Thus, each centre is equipped with computers and accessories, internet facilities with alternative power source provided via solar power. The e-learning package is meant to enable users to train themselves on a variety of subjects from secondary school level upwards. They also help to minimize migration from rural to urban areas by providing the means for rural dwellers and the semi-urban population to become part of the evolving knowledge-based society, and to participate in an economy that is driven by ICT. NITDA (2014) believes that 
RITCs will promote decentralization, enable local administrative units to be upgraded, plan development activities, and enable local governments to work closely with NGOs and community organizations. The deployment of RITCs across Nigeria is part of NITDA's initiative of meeting the targets of the Millennium Development Goals by providing internet access to the under-served communities. The aim is to have at least one centre in each of the 774 local government areas of the country (NITDA, 2014). This will contribute in rural information services delivery.

Community Radio Stations: According to Al-hassan, Andani and Abdul-Malik (2011), community radio is a type of radio service that offers a model of radio broadcasting beyond commercial and public service. Community radio broadcasting serves geographic communities and communities' interest. The content of broadcasting is largely popular and relevant to a local/specific audience but which may often be overlooked by commercial or mass-media broadcasters. Community radio stations are operated, owned, and driven by the communities they serve. Community radio is not-for profit and provides a mechanism for facilitating individuals, groups, and communities to tell their own diverse stories, to share experiences, and in a media rich world to become active creators and contributors of media. In many parts of the world today, community radio acts as a vehicle for the community and voluntary sector, civil society, agencies, NGOs and citizens to work in partnership to promote community development. By the core aims and objectives of this model of broadcasting, community radio stations often serve their listeners by offering a variety of content that is not necessarily provided by the larger commercial radio stations.

Study by Chapman, Blench, Kranjac-Berisavljevic' and Zakariah (2003) report that the growth of rural radio stations reflects both the improvements in information and communication technologies and the shifting of development paradigm towards a more participatory style of information and knowledge transfer. In other words, community radio stations serve as an avenue for participatory communication and as a tool relevant in both economic and social development of rural dwellers. Al-hassan, Andani and Abdul-Malik (2011), quoting Kumar, noted that community radio can play a significant role at the grass roots level for rural development. For instance, issues of poverty, agriculture, gender inequality, education, social problems among others could be the focus for programming. In exploring the importance of sharing information locally and the opening up of wider information networks for farmers in Northern Ghana with reference to vernacular radio programmes, Chapman, Blench, Kranjac-Berisavljevic' and Zakariah (2003) found that rural radio is effective in improving the sharing of agricultural information by remote rural farming communities. Radio in this regard provides a set of participatory communication techniques that support agricultural extension efforts by using local languages to communicate directly with farmers and listeners' groups.

\section{How Will the Information Infrastructure Address Information Delivery and Development of Rural Communities?}

The descriptions of the various information infrastructures, which are community information centres, rural school media centres, rural information and communication technology centres 
as well as community radio stations shows that they have significant roles to play in addressing the information needs of rural dwellers. These information needs are mainly in the areas of agriculture, health, education, economic and other issues. Take for instance, it can be inferred that the absence of school library media centres and the requisite information, human, and infrastructural resources in various public primary and secondary schools in Nigeria is the major contributory factor of growing poor reading culture in the country. However, with the availability of requisite information materials and empowered human resources (librarians and library/information officers), the rural school media centres will work towards inculcating reading habits, information handling and utilisation skills in pupils and students thereby addressing poor reading culture that is ravaging Nigerian society. Also, the use of audio-visual resources for easy assimilation by pupils can be enhanced in school media centres, if provided.

In the case of community information centres (CICs), they can function as avenues for documenting indigenous knowledge and culture of the people for generations to come. CICs can also serve as learning resource centres for the mass literacy, adult and non-formal education programmes of states and federal government across Nigeria. Various research findings on agricultural development programmes that result in improved production of crops and livestock are hardly disseminated to rural farmers by agricultural extension officers (Uzuegbu\&Uzuegbu, 2013). CICs can come in here to serve their people in that capacity by acting as liaison centres between research institutes and rural farmers. In addition, acceptable health practices for healthy living and diseases prevention strategies can be disseminated to rural dwellers with the use of projectors in their CICs.

In addition, CICs and RITCs can be avenues for facilitating access to computer trainings and applications, thereby making the rural populace to be digitally literate. They can also contribute in making the rural dwellers to access and participate in e-governance initiatives of federal and state governments. CICs and RITCs will also serve as centres of excellence for facilitating various distance learning programmes of National Open University of Nigeria (NOUN) for the inhabitants of rural communities that are interesting in further education.

For community radio stations, their information dissemination system to people at their various houses and locations is unique. Radio is an affordable audio for accessing information. Such can be used for addressing virtually all areas of information needs as applicable to rural dwellers, be it contemporary agricultural practices, personal hygiene and other health behaviours, economic policies and programmes of government for rural dwellers, political and democratic participation, scholarship schemes for rural communities, and the likes. Thus summary of it all is that all the identified rural information infrastructures are essential and are required to facilitate and fast-track rural community development and reduce rural-urban migration among the citizens.

\section{Conclusion and Recommendations}

This paper has articulated the various information infrastructures that will facilitate information delivery and development of rural communities in Nigeria. These infrastructures, with their requisite human, information and other associated resources are expected to serve 
as avenues and access points for meeting the information needs of rural dwellers, which are predominantly in the areas of agriculture, health, economic issues and education, among others. But the question that is of utmost concern is: do these information infrastructures exist in our rural communities in Nigeria? It is a fact that community information centres are hardly seen in Nigeria for providing information services to rural dwellers. Where they exist, the dilapidated nature and state of resources, including information, human and infrastructural, will not be able to deliver the requisite information needs for rural dwellers. Public primary and secondary schools in rural communities in Nigeria exist without libraries and school media centres. NITDA, which is under Federal Ministry of Communication Technology is establishing RITC across Nigeria, but unfortunately majority of the so-called RITC established are not located in core rural areas. Some community-based radio stations are emerging in Nigeria, but they are privately owned, which means they are developed for economic reasons, and thus may not direct their services towards addressing core information and developmental needs of rural dwellers.

Igwe and Onah (2013) articulated the challenging scenario confronting the provision of library and information services in contemporary Nigeria to include: absence of relevant government policies for overall development of libraries and information services in all sectors of the economy; poor state of existing public libraries; absence of community libraries and information centres; inadequacy of human, infrastructural and information resources in the existing libraries; poor state and or absence of libraries in public primary and secondary schools; and some passive library and information practitioners in Nigeria. This is the situation.

Having seen the unacceptable state of information infrastructure in rural communities in Nigeria, it is therefore recommended that:

- Federal government should develop a workable policy for addressing rural information infrastructure. Federal and state governments should work together, plan and integrate rural information infrastructure in their programmes that will result in establishing community information centres, rural school media centres, rural ICT centres as well as community radio stations in the nation's rural areas and hinterlands.

- Public libraries in Nigeria should be given adequate attention, decentralized to local government areas, and empowered to provide core services for the rural dwellers.

- Government's efforts in developing RITCs is commendable, but effort should be made towards situating them in core rural areas, not only for addressing rural information needs, but also for empowering the rural populace to be digitally literate so as to embrace fast emerging e-government initiatives in the country.

- Poor reading culture, which is more pronounced in rural and semi-urban centres will continue to ravage the Nigerian society except establishment of functional school library and media resource centres as well as engagement of the services of 
library/information practitioners, for teaching reading habits and information literacy skills to students.

- Above all, sincerity of federal and state governments of Nigeria matters a lot. Those in authority must see the people as their priority, carry out real community survey, identify and implement relevant programmes such as development of requisite information infrastructure for rural community development.

\section{References}

Aina, L. O. (2004). Library and information science text for Africa. Ibadan, Nigeria: Third World Information Services.

Akpomuvie, O. B. (2010). Self-help as a strategy for rural development in Nigeria: a bottom-up approach. Journal of Alternative Perspectives in the Social Sciences, 2(1), 88-111.

Al-hassan, S., Andani, A., \& Abdul-Malik, A. (2011). The role of community radio in livelihood improvement: the case of Simli Radio. Field Actions Science Reports, 5. Retrieved October 20, 2014, from http://factsreports.revues.org/869

Babalola, Y. T. (2013). Nigeria's information infrastructure policy: implications for e-government. Arabian Journal of Business and Management Review, 2(11), 8-15.

Chapman, R., Blench, R., Kranjac-Berisavljevic, G., \& Zakariah, A. B. T. (2003). Rural radio in agricultural extension: the example of vernacular radio programmes on soil and water conservation in Northern Ghana. Agricultural Research \& Extension Network. Paper No. 127.

Chigbu, U. E. (2012). Village renewal as an instrument of rural development: evidence from Weyarn, Germany. Community Development, 43(2), 209-224. http://dx.doi.org/10.1080/15575330.2011.575231

Diso, L. I. (2005). Information production, transfer, and delivery: Mass information work and television journalisms dilemma in Nigeria. The International Information and Library Review, 37, 285-294. http://dx.doi.org/10.1016/j.iilr.2005.08.003

Etebu, A. T. (2009). Information for rural communities: A solution for sustainable development in the Niger Delta. Library Philosophy and Practice. Retrieved September 27, 2014, from http://digitalcommons.unl.edu/libphilprac

Hansen, E. (1995). A community library initiative. SAILIS Newsletter, 15(3), 3-5.

Harande, Y. I. (2009). Information services for rural community development in Nigeria. Library Philosophy and Practice. Retrieved October 18, 2014, from http://www.webpages.uidaho.edu/ mbolin/harande.htm

Igwe, K. N. (2012). LIS 311 Introduction to information science. Department of Library and Information Science, School of Communication and Information Technology, Federal Polytechnic Offa, Kwara State, Nigeria.

Igwe, K. N., \& Onah, E. A. (2013). Issues and concerns in the service delivery system of 
libraries to users in the globalization era. In A. O. Issa, K. N. Igwe \& C. P. Uzuegbu (Eds.), Provision of library and information services to users in the era of Globalisation (pp. 20-41). Lagos, Nigeria: Waltodanny Visual Concept.

Issa, A. O. (1998). The information needs of rural dwellers in Kwara state. In Tijjani.A et al. (Eds.), Issues in information provision: Nigerian perspectives (pp. 13-21). Zaria, Nigeria: NALISE.

Issa, A. O., Omopupa, K. T., \& Salman, A. A. (2012). Rural information provision for national development: A study of Kwara North senatorial district of Kwara State, Nigeria. PNLA Quaterly, 76(3). Retrieved October 21, 2014, from http://unllib.unl.edu/LPP/PNLA\%20Quarterly/PNLAQ76-3.htm

Kamba, M. A. (2009). Access to information: The dilemma for rural community development in Africa. Retrieved September 26, 2015, from http://globelics2009dakar.merit.unu.edu/papers/1238296264_MA.pdf

Momodu, O. M. (2012). Rural libraries and community development in Nigeria. International Journal of Basic, Applied and Innovative Research, 1(3), 91-97.

Moseley, M. J. (2003). Rural development: principles and practice. London: Sage Publishers.

Mtega, W. P. (2012). Access to and usage of information among rural communities: A case study of Kilosa District Morogoro Region in Tanzania. Partnership: the Canadian Journal of Library and Information Practice and Research, 17(1). Retrieved October 26, 2014, from https://journal.lib.uoguelph.ca/index.php/perj/

National Information Technology Development Agency. (2014). Rural information technology resource centres. Retrieved October 20, 2014, from http://www.nitda.gov.ng/post2.html

New Zealand Social Infrastructure Fund. (2009). What is social infrastructure. Retrieved October 12, 2014, from http://www.nzsif.co.nz/SocialInfrastructure/What-is-Social-Infrastructure/

Nnadozie, C. O., Egwim, F. O., \& Ossai-Onah, V. O. (2010). An evaluative study of community-based library and information services in Mbaitoli LGA of Imo State, Nigeria. The Information Manager, $10(1$ \& 2), 55-62.

Nwokoma, A. (2012). Building IT knowledge centres as corporate social responsibility for Nigerian communities' sustainable economic development. Journal of Educational and Social Research, 2(10), 18-22.

Opara, U. N. (2014). The role of information and its communication for rural development in Nigeria. Invited Lead Paper Delivered by Dr. U.N. Opara on $27^{\text {th }}$ October, 2014 at the $1^{\text {st }}$ Annual National Conference of The Ebonyi State Chapter of the Nigerian Library Association Held at the Ebonyi State Central Library, Abakaliki, Nigeria.

Saleh, A. G., \& Lasisi, F. I. (2011). Information needs and information seeking behavior of rural women in Borno State, Nigeria. Library Philosophy and Practice. Retrieved October 20, 
2014, from http://www.webpages.uidaho.edu/ mbolin/saleh-lasisi2.htm

Shakeel, M. (2001). Comparing urban and rural knowledge costs. Electronic Journal of Information Systems in Developing Countries, 4(2), 1-13.

Uhegbu, A. N. (2014). The role of information in grassroots development. Keynote Address Presented by Professor A.N. Uhegbu on $27^{\text {th }}$ October, 2014 at the $1^{\text {st }}$ Annual National Conference of The Ebonyi State Chapter of the Nigerian Library Association Held at the Ebonyi State Central Library, Abakaliki, Nigeria.

Uzuegbu, C. P., \& Uzuegbu, C. L. (2013). Community information centre services: a prospective pathway to national transformation and development in Nigeria. In A. O. Issa, K. N. Igwe \& C.. Uzuegbu (Eds.), Provision of library and information services to users in the era of Globalisation (pp. 1-19). Lagos, Nigeria: Waltodanny Visual Concept

UNESCO. (n.d.). Community information and technology centres: focus on South East Asia. Bangkok: UNESCO. Retrieved October 15, 2014, from www.unesco.org/new/.../CI/.../programme_doc_telecentre_study_en.pdf

UNESCO/IFLA. (n.d). School library manifesto. Retrieved October 12, 2014, from http://www.unesco.org/webworld/libraries/manifestos/school_manifesto.htm

Ward, N., \& Brown, D. L. (2009). Placing the rural in regional development. Regional Studies, 43(10), 1237-1244. http://dx.doi.org/10.1080/00343400903234696

\section{Copyright Disclaimer}

Copyright for this article is retained by the author(s), with first publication rights granted to the journal.

This is an open-access article distributed under the terms and conditions of the Creative Commons Attribution license (http://creativecommons.org/licenses/by/3.0/). 